\title{
GENETIC VARIABILITY ASSOCIATED WITH ANGIOTENSIN CONVERTING ENZYME (ACE) GENE POLYMORPHISM IN SPORTSMEN PURSUING DIFFERENT SPORTS
}

\author{
Algimantas Paulauskas*, Asta Danileviciutè ${ }^{*}$ Tadas Povilaitis*, and Jonas Poderis** \\ * Vytautas Magnus University, K. Donelaičio g. 58, Kaunas, LT-44248, LITHUANIA \\ ** Lithuanian Academy of Physical Education, Sporto 6, Kaunas, LT-44221, LITHUANIA
}

Communicated by İzaks Rašals

\begin{abstract}
The purpose of the study was to determine angiotensin converting enzyme (ACE) gene polymorphisms in sportsmen and sedentary individuals and to evaluate the differences in frequencies of ACE genotype and allele distribution among sportsmen who are involved in different sports. In this study 255 participants were analysed: 116 sedentary individuals and 139 sportsmen. Sportsmen were differentiated into separate groups according to various sports: endurance, strength requiring, cyclic and acyclic sports. DNA was purified from peripheral blood with a DNA purification kit "Fermentas". ACE gene polymorphic region was amplified by polymerase chain reaction (PCR). DNA electrophoresis was used to separate DNA fragments by size. Bands were visualised under ultra violet (UV) light. The frequency of D allele was higher than I allele in sedentary individuals; the sportsmen had higher frequency of I allele. The $\mathrm{X}^{2}$ test showed allele selection in sedentary individuals. Frequency of the I allele among the individuals who belong to endurance requiring sports was higher than was the $D$ allele, while among the individuals who belong to sports requiring strength, the $\mathrm{D}$ and I allele frequences were equal. Differences in the individuals who belong to acyclic sports group were not significant - the frequency of I allele was much higher than $\mathrm{D}$ in the cyclic sports group. D allele frequency was twice higher than I allele among wrestlers.
\end{abstract}

Key words: angiotensin converting enzyme (ACE), gene polymorphism, sportsmen.

\section{INTRODUCTION}

A number of investigators have indicated that individual variations in human physical performances reflect both environmental factors, such as physical, biomechanical, physiological, metabolic, behavioural, psychological, and social characteristics, and genetic element interaction (Ohno et al., 2005). The effects of environmental factors on endurance performance are well documented, whereas few genetic loci of influence have been identified. One gene loci of interest is angiotensin I-converting enzyme (ACE) (Collins et al., 2004). ACE is part of the renin-angiotensin system. The inactive form of the angiotensin hormone, angiotensinogen, is cleaved by renin to produce angiotensin I. ACE then catalyses the conversion of angiotensin I to produce angiotensin II, which is the physiologically active form of the hormone (Thompson et al., 2006). In addition, local renin- angiotensin systems may influence tissue growth. A polymorphism of the human $A C E$ gene has been described in which the deletion $(D)$ rather than insertion $(I)$ allele is associated with higher activity of tissue ACE (Montgomery et al., 1998). Several studies identified an association between the pres- ence of a specific allele of the gene encoding the angiotensin-converting enzyme (ACE) and an individual's endurance or strength capacity (Gayagay et al., 1998; Folland et al., 2000; Woods et al., 2000; Williams et al., 2004). Interestingly, some studies have refuted the relationship between the enzyme and increased endurance or strength (Karjalainen et al., 1999; Taylor et al., 1999; Rankinen et al., 2000). The aim of this study was to determine angiotensin converting enzyme (ACE) gene polymorphisms in sportsmen and sedentary individuals.

\section{MATERIALS AND METHODS}

The experimental protocol used for this study was approved by the the Bioethical Committee of Lithuania. Blood was collected from 255 participants: 116 sedentary individuals (control group) and 139 sportsmen. Sportsmen were differentiated into separate groups according to various sports: endurance, strength requiring, cyclic and acyclic sports. Blood was collected by venipuncture into tubes with EDTA or citrate and kept at $-20{ }^{\circ} \mathrm{C}$ temperature. DNA was puri- 
fied from peripheral blood with a DNA purification kit (MBI "Fermentas" Vilnius Lithuania). DNA concentrations were quantified with a spectrophotometer (Eppendorrf BioPhotometer). PCR was performed in a final volume of $20 \mu \mathrm{L}$ in a mixture containing $5 \mu \mathrm{g}$ DNA, $2 \mathrm{mM} \mathrm{MgCl}_{2}, 0.2$ mM dNTP, 1x PCR buffer (MBI "Fermentas" Vilnius, Lithuania), $10 \mathrm{pmol}$ of each primer and $0.2 \mathrm{U}$ of Taq polymerase. The sense primer was

\section{5'-CTGGAGACCACTCCCATCCTTTCT-3',}

and the antisense primer was

5'-GATGTGGCCATCACATTCGTCAGAT-3' (Mayer $e t$ al., 2002). Amplification was performed in an Eppendorf Mastercycler gradient. The samples were initially denaturated for one minute at $95{ }^{\circ} \mathrm{C}$, subsequent cycles were denaturated at $95{ }^{\circ} \mathrm{C}$ for 30 second, annealing at $55^{\circ} \mathrm{C}$ for 30 seconds, extension at $69^{\circ} \mathrm{C}$ for 30 seconds; 28 cycles were performed. Final extension was at $72{ }^{\circ} \mathrm{C}$ for ten minutes. PCR products were electrophoresed in $1.5 \%$ agarose gels and were visualized by ethidium bromide staining. The polymorphisms detected by means of PCR were evident as an approximately 490-bp fragment in the presence of the insertion $(I)$ allele and as an approximately 190-bp fragment in the absence of insertion $(D)$ allele (Fig. 1). DNA bands visualised by UV transillumination (EASY Win32, Herolab, Germany). To characterise the genetic diversity we computed the mean number of alleles per locus (A), mean observed heterozigosity per locus (Hedrick, 1983) and Nei's (Nei, 1978) unbiased estimates of the mean expected heterozygosity $\left(\mathrm{H}_{\mathrm{e}}\right)$ using the Excel Microsatellite ToolKit (Park, 2001). Loci were tested for departure from Hardy-Weinberg equilibrium (HWE) using the $\chi^{2}$ (chisquare) and exact-test by Guo \& Thompson (Guo and Thompson, 1992) as implemented in Biosys-2 (Swofford and Selander, 1997).

\section{RESULTS}

We evaluated the differences in frequencies of the $A C E$ genotype and allele distribution among sportsmen who are involved in different sports and in sedentary individuals.

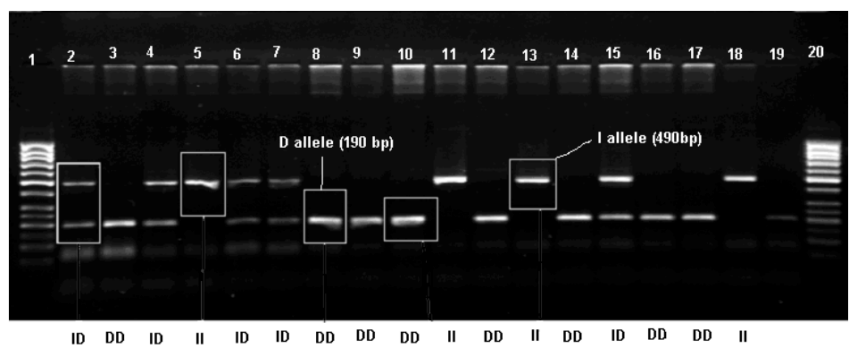

Fig. 1. Determination of angiotensin-converting enzyme (ACE) genotypes $(D D, I D$ and $I I)$ by PCR using $A C E$ primers. Lane 1 and 20 are markers, lanes $2,4,6$, and 7 are $I D$ genotype; lane 5, 11, 13, and 18 are $I I$ genotype, lanes $3,8,9,10,12,14,16,17$ and 19 are $D D$ genotype.

Among sportsmen, the $D D$ genotype was detected in $33, I D$ genotype in 36 and $I I$ genotype in 42 individuals. Among sedentary groups, the $D D$ genotype was detected in $42, I D$ in 47 , and $I I$ in 27 individuals. The $D D$ genotype frequency differs between these two groups (sportsmen 0.237, sedentary group 0.362) (Fig. 3). The frequency of $D D$ genotype was $13 \%$ higher in sedentary individuals than in sportsmen. The $I D$ and $I I$ genotypes were $6 \%$ and $7 \%$, respectively, higher in sportsmen than in sedentary individuals. In sedentary individuals the $D$ allele was detected in a $13 \%$ higher frequency than the $I$ allele, but in sportsmen the $I$ allele had a $7 \%$ higher frequency than the $D$ allele. The above results are consistent with previous studies (Šventoraityte et al., 2006; Scanavini et al., 2002).

We also examined the frequencies of $A C E$ genotype and allele distribution among sportsmen involved in different types of sports: endurance sports (football, marathon etc.) (81 individuals) and strength sports (wrestle, discus throw etc.) (59 individuals). The $A C E I / D$ frequencies of polymorphism endurance of sportsmen with $D D$ genotype was 16 , $I D-40, I I-25$ individuals, in strength sports: $D D-$ $17, I D-24, I I-17$. The frequency of I allele among endurance sportsmen was higher than the $D$ allele, while in strength sports the amounts of $D$ and $I$ alleles were equal (Fig. 2). Frequency of the $D D$ genotype was higher (0.298) in individuals under strength training. The $I D$ genotype was detected more in individuals in endurance sport (Fig. 3).

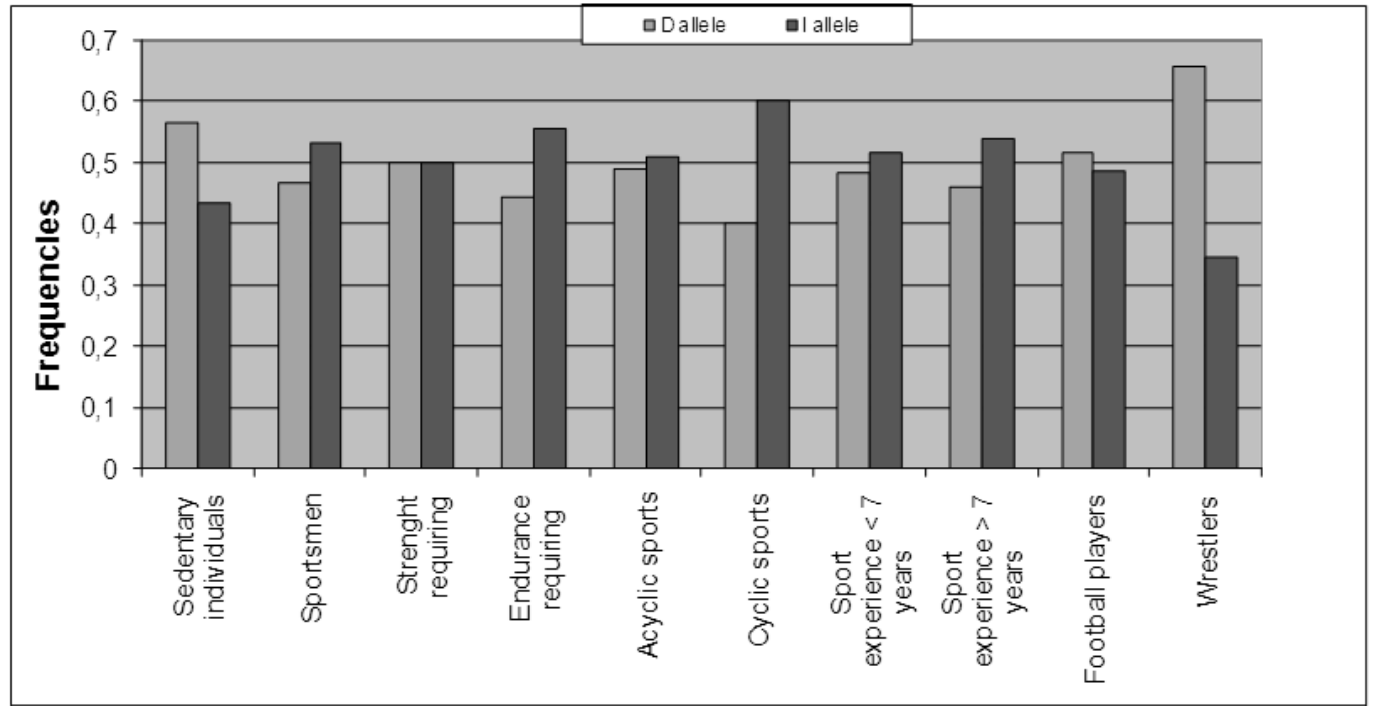

Fig. 2. Frequency of Angiotensin-Converting Enzyme (ACE) gene $D$ and $I$ alleles in analysed groups. Frequency of I allele among the individuals who are in endurance requiring sports was higher than the $D$ allele, while among the individuals who are in sports requiring strength, the amount of $D$ and $I$ alleles were equal. 


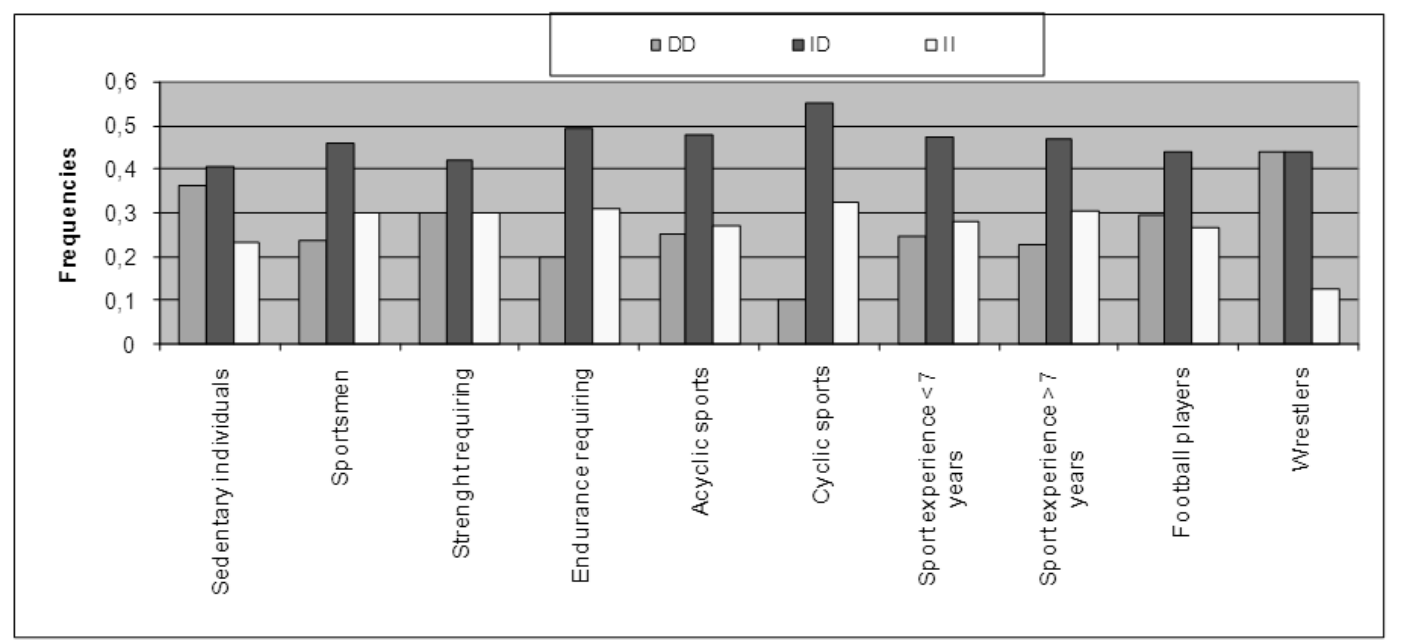

Fig. 3. Frequency of Angiotensin-Converting Enzyme (ACE) gene $I / D$ polymorphism genotypes in analysed groups. In the sportsmen group the $D D$ genotype was detected in 33 , the $I D$ genotype in 36 and $I I$ genotype in 42 individuals. Among sedentary groups, the $D D$ genotype was detected in $42, I D$ in $47, I I$ in 27 individuals. Among these two groups $D D$ genotype frequency is very different (sportsmen 0.237, sedentary group 0.362 ).
The individuals in endurance training were further grouped by: cyclic sports (sports where you repeat an action over and over) (40 individuals) and acyclic sports (same movements are not repeated over and over) (44 individuals). Frequencies of alleles in these groups were: cyclic group $I$ allele $-0.60, D$ allele -0.40 ; in acyclic group: $I$ allele $0.510, D$ allele -0.490 (Fig. 2). In cyclic groups, the $D D$ genotype was observed in 5, ID in 33 and II in 13 individuals; in the acyclic group, 11, 21, and 12, respectively.

Comparing the football players and wrestlers, the $D$ allele (0.656) frequency was twice higher than the I allele (0.344) among wrestlers; in football players allele frequencies were $D-0.515, I-0.485$ (Fig. 2). Genotype distribution among football players was: $D D$ genotype in $10, I D$ in 15 , and $I I$ in 9 individuals; among wrestlers: $D D$ in $7, I D$ in 7 , II in two individuals.

The $D D$ genotype has previously been associated with health of sportsmen as it may be related with hypertrophy that can shorten the career of sportsmen. All participants were grouped by sportsmen's experience: up to seven years, and more than seven years. Allele frequencies did not significantly differ between the groups: in the group up to seven years allele frequency was $D(0.484), I(0.516)$, in the group more than seven years $D-0.460, I-0.540$ (Fig. 2 ). By genotypes the distributions up to seven years were $D D-15, I D-29, I I-17$; and more than seven years: $D D-17, I D-35, I I-23$.

\section{DISCUSSION}

Genetic distance among different groups of sportsmen in genetic frequencies was determined to produce a genetic dendrogram. Wrestlers are most genetically separated from other groups (Fig. 4). The sedentary group and cyclic sport group were also separated from the other groups. Strength training sportsmen, acyclic sportsmen and sportsmen having experience up to seven years, are genetically similar. The football players differed slightly from these three groups. Participants of endurance requiring sportsmen and sportsmen having experience more than seven years by genotype were similar to the general sportsmen group. The

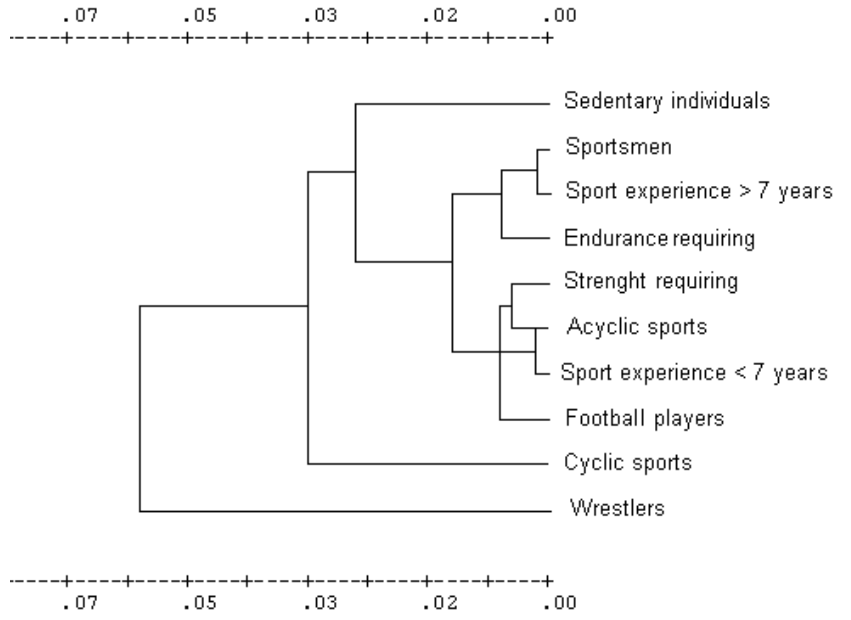

Fig. 4. Frequencies of angiotensin-converting enzyme (ACE) gene I/D genotypes in the analyzed groups. Genetic distance among different groups of sportsmen per genetic frequencies is shown, wrestlers genetically differ from the other groups. Participants of sedentary group and cyclic sports group are separated from other groups as individual groups.

frequency of I allele was detected more often in sportsmen than in sedentary individuals (Scanavini et al., 2002; Tsianos et al., 2004; Ohno et al., 2005). However, according to genotype frequency distribution among sedentary individuals (control group) the results differ from the work of many other authors (Mathew et al., 2001; Thomson et al., 2006). $X^{2}$ criteria (3.768) were high in sedentary individuals due to high divergence genotype frequencies, from the Hardy-Weinberg equilibrium and this divergence was not random. This cannot be explained by gene flow or inbreeding, but rather by natural selection. Earlier studies have associated $D D$ genotype with cardiovascular diseases (Schunkert et al., 1994; Agerholm-Larsen et al., 2000; Crisan et al., 2000), and therefore, this genotype may be related with poor health.

Comparing genotype frequencies of individuals in endurance requiring sports with strength sports, in the latter group there was a higher $D D$ and lower $I D$ genotype frequency than in endurance requiring sports, while II genotype fre- 
quencies were similar. Differences of $D D$ genotype we can explain by hypotheses of others authors that the $D D$ genotype may be associated with an increased amount of fast fiber in skeletal muscles (Zhang et al., 2003).

While cyclic and acyclic sports groups belong to endurance requiring sports, among these groups genotype frequencies were very different. In the acyclic sport group the $D D$ genotype occurred more frequently. Genetic variety among cyclic and acyclic sports per $I / D$ polymorphism was not analysed. Zhang (2003) and Yang (1996) found that the $D D$ genotype is associated with faster response to stress. Therefore, acyclic sportsmen have the biggest advantage among sportsmen, as stress is more common and the $D$ allele and $D D$ genotype frequencies higher in acyclic sports.

Our results do not support other studies that found that polymorphism of ACE gene is associated with health index of sportsmen (Rankinen et al., 2000) and hypertrophy (Schunkert et al., 1994; Jan Dancer et al., 1995; Angerholm-Larsen et al., 2000; Crisan et al., 2000).

Allele and genotype differences among football players and wrestlers were higher than expected. These groups were separate from other investigated groups, but in football players the alleles and genotype frequencies were close to those in the acyclic sport group. This similarity can be expected as football belongs to the acyclic sport group. The wrestler's group was separated from other groups (Fig. 4). These results concur with those of other authors (Ohno et al., 2005), who found that $D D$ genotype provides specific adaptability of organism to manual strain. High $D$ allele frequency is characteristic of groups incurring stress more often. In conclusion we can hypothesize, that in public world stress is factor of selection, and can explain why a higher frequency of $D$ allele is found in persons in stress situations.

\section{ACKNOWLEDGEMENTS}

This study was partially supported by the Lithuanian State Science and Studies Foundation and the Lithuanian National Olympic Committee.

\section{REFERENCES}

Agerholm-Larsen, B., Nordestgaard, B.G., Tybjerg-Hansen, A. (2000). ACE gene polymorphism in cardiovascular disease meta-analyses of small and large studies in whites. Arterioscler. Thromb. Vasc. Biol., 20, 484-492.

Collins, M., Xenophontos, S.L., Cariolou, M.A., Mokone, G.G., Hudson, D.E., Anastasiades, L., and Noakes, T.D. (2004). The ACE gene and endurance performance during the South African Ironman Triathlons. Med. Sci. Sports Exerc., 36, 13.

Crisan, D., Carr, J. (2000). Angiotensin I-converting enzyme: Genotype and disease associations. J. Mol. Diag., 2(3), 105-115.

Folland, J., Leach, B., Little, T., Hawker, K., Myerson, S., Montgomery, H., Jones, D. (2000). Angiotensin-converting enzyme genotype affects the response of human skeletal muscle to functional overload. Exp. Physiol., 85, 575-579.

Gayagay, G., Yu, B., Hambly, B., Boston, T., Hahn, A., Celermajer, D.S., Trent, R.J. (1998). Elite endurance athletes and the ACE I allele: The role of genes in athletic performance. J. Hum. Genet., 103, 48-50.
Guo, S.V., Thompson, E.A. (1992). Performing the exact test of Hardy-Weinberg proportion for multiple alleles. Biometrics, 48, 361-372.

Karjalainen, J., Kujala, U.M., Stolt, A., Mäntysaari, M., Viitasalo, M., Kainulainen, K., Kontula, K. (1999). Angiotensin gene M235T polymorphism predicts left ventricular hypertrophy in endurance athletes. J. Am. Coll. Cardiol., 34, 494-499.

Mathew, J., Basheeruddin, K., Prabhakar, S. (2001). Differences in frequency of the deletion polymorphism of the angiotensin-converting enzyme gene in different ethnic groups. J. Angiology, 52(6), 375-379.

Mayer, N.J., Forsyth, A., Kantachuvesiri, S., Mullins, J.J., Fleming, S. (2002). Association of the $D$ allele of the angiotensin I converting enzyme polymorphism with malignant vascular injury. J. Clin. Pathol., 55(1), 29-33.

Montgomery, H.E., Marshall, R., Hemingway, H., Myerson, S., Clarkson, P., Dollery, C., Hayward, M., Holliman, D.E., Jubb, M., World, M., Thomas, E.L., Brynes, A.E., Saeed, N., Barnard, M., Bell, J.D., Prasad, K., Rayson, M., Talmud P.J., and Humphries, S.E. (1998). Human gene for physical performance. Nature, 393, 221-222.

Nei, M. (1978). Estimation of average heterozygosity and genetic distance from a small number of individuals. Genetics, 89, 583-590.

Ohno, H., Kizaki,T., Suzuki, K., Hitomi, Y., Nakano, N., Sakurai, T., Ogiwara, R., Sakurai, T., Izawa, T., Noguchi, I., Nagasawa, J., Ohnuki, Y., Takemasa,T., Nukita, M., and Haga, S. (2005). Is angiotensin I-converting enzyme $I / D$ polymorphism associated with endurance performance and/or high altitude adaptation? Adv. Exerc. Sports Physiol., 11(2), 41-54.

Ohno, T., Kawazu, S., Tomono, S. (1996). Association analyses of the polymorphisms of angiotensin-converting enzyme and angiotensinogen genes with diabetic nephropathy in Japanese non-insulin-dependent diabetics. Metabolism, 45, 218-222.

Park, S.D.E. (2001). Trypanotolerance in West African cattle and the population genetic effects of selection. Ph.D. thesis, University of Dublin.

Rankinen, T., Wofarth, B., Simoneau, J. A., Maier-Lenz, D., Rauramaa, R., Rivera, M. A., Boulay, M. R., Chagnon, Y. C., Perusse, L., Keul, J., Bouchard, C. (2000). No association between the angiotensin-converting enzyme $I D$ polymorphism and elite endurance athlete status. J. Appl. Physiol., 88, 1571-1575.

Scanavini, D., Bernardi, F., Castoldi, E., Conconi, F. and Mazzoni, G. (2002). Increased frequency of the homozygous II ACE genotype in Italian Olympic endurance athletes. Eur. J. Hum. Gen., 10, 576-577.

Schunkert, H., Hense, H.W., Holmer, S. R., Stender, M., Perz, S., Keil, U.,. Lorell, B.H., and Riegger, G. (1994). Association between a deletion polymorphism of the angiotensin-converting-enzyme gene and left ventricular hypertrophy. New. Eng. J. Med., 330,1634-1638.

Šventoraitytė, J., Venskaitytė, E., Poderytė, K., Paulauskas, A. (2006). Angiotenziną konvertuojančio fermento geno polimorfizmo sąsajos su širdies ir kraujagyslių sistemos funkcijos ypatybėmis [The angiotensin-converting-enzyme gene polymorphism's association with peculiarities of cardiovascular function]. Sporto Mokslas, 46(4), 65-69 (in Lithuanian).

Swofford, D.L., Selander, R.B. (1997). BIOSYS-2: A Computer Program for the Analysis of Allelic Variation on Population Genetic and Biochemical Systematics. Colorado State University. Champaign: Illinois Natural History survey.

Taylor, R.R., Mamotte, C.D., Fallon, K., Van Bockxmeer, F.M. (1999). Elite athletes and the gene for angiotensin-converting enzyme. J. Appl. Physiol., 87, 1035-1037.

Thompson, W.R., Binder-Macleod, S.A. (2006). Association of Genetic Factors with Selected Measures of Physical Performance. Phys. Ther., 86(4), 585-591.

Tsianos, G., Sanders, J., Dhamrait, S., Humphries, S., Grant, S., Montgomery, H. (2004). The ACE gene insertion/deletion polymorphism and elite endurance swimming. Eur. J. Appl. Physiol., 92, 360-362. 
Williams, A.G., Dhamrait, S.S., Wootton, P.T.E., Day, S.H., Hawe, E., Payne, J.R., Myerson, S.G., World, M., Budgett, R., Humphries, S.E., Montgomery, H.E. (2004). Bradykinin receptor gene variant and human physical performance. J. Appl. Physiol., 96, 938-942.

Received 10 October 2007
Woods, D.R., Humphries, S.E., Montgomery, H.E. (2000). The ACE I/D polymorphism and human physical performance. J. Trends Endocr. Metab., 11, 416-420.

Yang, G., Wan, Y., Zhu, Y. (1996). Angiotensin II — an important stress hormone. J. Biol. Sign. 5(1), 1-8.

Zhang, B., Tanaka, H., Shono, N., Miura, S., Kiyonaga, A., Shindo, M., Saku, K. (2003). The I allele of the angiotensin-converting enzyme gene is associated with an increased percentage of slow-twitch type I fibers in human skeletal muscle. Clin. Genet., 63(2),139-144.

AR ANGIOTENSĪNA KONVERTĒJOŠĀ ENZĪMA (AKE) GĒNA POLIMORFISMU SAISTĪTĀ GENĒTISKĀ VARIABILITĀTE SPORTISTIEM, KURI NODARBOJAS AR DAŽĀDIEM SPORTA VEIDIEM

Dažādu sporta veidu sportistiem ticami atšķiras angiotensīna konvertējošā enzīma (AKE) gēna $D$ un $I$ alēḷu frekvences. 